\title{
Development of a Magnetic Capture Hybridization Real-Time PCR Assay for Detection of Tumorigenic Agrobacterium vitis in Grapevines
}

\author{
Kameka L. Johnson, Desen Zheng, Supaporn Kaewnum, Cheryl Lynn Reid, and Thomas Burr
}

Plant Pathology and Plant-Microbe Biology, Cornell University, Geneva, NY 14456.

Accepted for publication 8 January 2013.

\begin{abstract}
Johnson, K. L., Zheng, D., Kaewnum, S., Reid, C. L., and Burr, T. 2013. Development of a magnetic capture hybridization real-time PCR assay for detection of tumorigenic Agrobacterium vitis in grapevines. Phytopathology 103:633-640.

Agrobacterium vitis, the causal agent of grape crown gall, can have severe economic effects on grape production. The bacterium survives systemically in vines and, therefore, is disseminated in propagation material. We developed an assay for use in indexing programs that is efficient and sensitive for detecting A. vitis in grape tissue. Initially, realtime polymerase chain reaction (PCR) primers specific for diverse tumorigenic strains of $A$. vitis were developed using the virD2 gene

sequence. To overcome the effects of PCR inhibitors present in plant tissue, DNA extraction methods that included magnetic capture hybridization $(\mathrm{MCH})$, immunomagnetic separation (IMS), and extraction with the Mo Bio Powerfood kit were compared. The assays incorporating MCH or IMS followed by real-time PCR were 10,000-fold more sensitive than direct real-time PCR when tested using boiled bacterial cell suspensions, with detection thresholds of $10^{1} \mathrm{CFU} / \mathrm{ml}$ compared with $10^{5}$ $\mathrm{CFU} / \mathrm{ml}$. DNA extraction with the Powerfood DNA extraction kit was 10fold more sensitive than direct real-time PCR, with a detection threshold of $10^{4} \mathrm{CFU} / \mathrm{ml}$. All three assays were able to detect A. vitis in healthyappearing grapevine cuttings taken from infected vines.
\end{abstract}

Agrobacterium vitis (26), formerly A. tumefaciens biovar 3 (22), is the causal agent of crown gall of grapevines and a limiting factor in grape production worldwide. In addition to causing crown gall, A. vitis is capable of causing a root necrosis that is specific to grapevine (10). A. vitis infections are induced at injury sites such as those caused by debudding, grafting, and freeze events. Management strategies for grape crown gall include planting resistant rootstock and scion varieties; however, the majority of Vitis vinifera varieties that have been tested are susceptible (9). Other management strategies include planting in field sites with no history of crown gall and the use of planting material free of the pathogen. A. vitis persists systemically in vines; therefore, whereas nursery stock may seem noninfected, cuttings may carry the pathogen (12). Once present in a field, the bacterium can persist in living and dead grape tissue in the soil for years, acting as a source of inoculum for new plants (12). Therefore, the use of clean planting material in areas with no history of the disease is the best option for control of this disease.

Indexing of grape propagation material for A. vitis has been severely limited by the assays that are very time consuming and lacking in sensitivity. One method our laboratory has used involves callusing of dormant cuttings followed by isolation of bacteria from the callus with the aid of semiselective culture media (23). Flushing grapevines with water followed by isolation on selective media and pathogenicity tests have also been attempted (33). Unfortunately, these methods can take 6 weeks or more for completion, and non-target bacteria may mask the presence of $A$. vitis. Polymerase chain reaction (PCR) assays have become increasingly more common for the detection of $A$. vitis, offering improved sensitivity and specificity $(14,29)$. Primers

Corresponding author: T. Burr; E-mail address: tjb1@ cornell.edu

http://dx.doi.org/10.1094/PHYTO-10-12-0267-R

This article is in the public domain and not copyrightable. It may be freely reprinted with customary crediting of the source. The American Phytopathological Society, 2013. must be able to distinguish between tumorigenic and nontumorigenic strains. The development of specific primers to address this issue targeted pathogenicity genes present on the $\mathrm{Ti}$ plasmid $(6,7,28)$. The limitations found with some of these primer sets is the inability to detect a wide range of $A$. vitis strains isolated from different geographic regions. Hence, one of our goals was to develop a primer set specific for detection of a broad range of tumorigenic A. vitis strains.

Real-time PCR represents a sensitive and fast approach for pathogen detection, with the advantage of being more sensitive and less time consuming than conventional PCR by not requiring further analysis such as gel electrophoresis. However, real-time PCR is still subjected to the limitations associated with inhibitor compounds in plant tissue and by the requirement for a threshold level of target nucleic acid. To reduce the effects of PCR inhibitors, we initially employed the Powerfood kit (Mo Bio Laboratories Inc., Carlsbad, CA) for DNA isolation from samples followed by conventional PCR for detection of tumorigenic strains of A. vitis. This method extracts DNA from all bacteria present in the sample and, therefore, target DNA can be diluted by DNA from non-target bacteria, which may result in false negatives. To address these issues, we tested enrichment of target nucleic acid via magnetic capture hybridization $(\mathrm{MCH})$ and immunomagnetic separation (IMS) followed by real-time PCR. MCH uses a biotinylated oligonucleotide probe, specific for the target sequence, conjugated to streptavidin-coated paramagnetic beads. Incubation of the bead/capture probe complex with a heterogeneous mix of nucleic acids allows target nucleic acid to anneal to the complementary sequences of the capture probe (21). A magnetic force is then applied to concentrate the bead-target DNA complex, and inhibitors and non-target DNA are rinsed away (21). IMS uses antibodies specific for the target bacterial cell that are bound to paramagnetic beads to concentrate target bacteria (35). The bacteria are isolated by magnetic force, and non-target cells and PCR inhibitors can then be washed away. Template DNA is released from bacterial cells for use in real-time PCR. MCH and IMS have been successfully used to enrich target nucleic acid for 
detection of pathogens in many research fields such as food microbiology, plant pathology, and soil microbiology $(1,15,17$, 19,34). Both methods have the potential to significantly improve the efficiency and sensitivity of grapevine indexing for $A$. vitis. The objective of this study was to compare technologies in the development of an efficient and sensitive method for the detection of $A$. vitis in grapevines and to implement assays on grapevine cuttings naturally infected with crown gall.

\section{MATERIALS AND METHODS}

Development of real-time PCR primers for detection of tumorigenic $\boldsymbol{A}$. vitis. It was previously shown that primers derived from the virD2 gene of the Ti plasmid are able to amplify a product from a high proportion of A. vitis strains (6). To improve on published virD2 primers, the conserved $5^{\prime}$ region of virD2 from seven $A$. vitis strains was amplified. Two primers, virD2-F and virD2-R, were designed based on the DNA sequence of the virD2 gene from A. vitis S4 (avi8212) (Table 1). The PCR reaction mixture contained $1 \mu \mathrm{l}$ of DNA, $1 \mu \mathrm{l}$ of forward primer $\operatorname{virD2}-\mathrm{F}(1 \mathrm{pM}), 1 \mu \mathrm{l}$ of reverse primer virD2-R $(1 \mathrm{pM}), 1 \mu \mathrm{l}$ of dNTP $(10 \mathrm{mM}$ each), $2.5 \mu \mathrm{l}$ of $10 \times$ reaction buffer, and 2 units of Taq DNA polymerase (New England Biolabs, Ipswich MA) in a total volume of $25 \mu \mathrm{l}$. The PCR reaction was conducted using the following program: initial denaturing at $94^{\circ} \mathrm{C}$ for $2 \mathrm{~min}$; then, 35 cycles of denaturing at $94^{\circ} \mathrm{C}$ for $15 \mathrm{~s}$, annealing at $52^{\circ} \mathrm{C}$ for $20 \mathrm{~s}$, and extension at $72^{\circ} \mathrm{C}$ for $60 \mathrm{~s}$; and final extension at $72^{\circ} \mathrm{C}$ for $5 \mathrm{~min}$. The PCR products were purified and ligated to pGEM-T easy vector (Promega Corp., Madison, WI). The ligation mixture was transformed into Escherichia coli JM109 and selected on Luria-Bertani agar plates supplemented with ampicillin (100 $\mu \mathrm{g} / \mathrm{ml}$ ). Plasmid DNA (pGEM harboring PCR product) was purified and sequenced at Cornell University Life Science Core Laboratories Center. The DNA sequences were analyzed with the software DNAStar Lasergene 10.1 (Madison, WI). Four primer pairs were designed within the sequenced fragments using the Integrated DNA Technologies PrimerQuest software (www.idtdna. com). The specificity of the primers in conventional PCR was tested using 27 A. vitis strains isolated from different geographic regions in the United States and internationally. Bacterial cells were collected from potato dextrose agar plates and suspended in $100 \mu \mathrm{l}$ of sterile high-performance liquid chromatography (HPLC) water. Cells were boiled for $10 \mathrm{~min}$ to lyse the bacterial cells. Cell debris was pelleted by centrifugation at 13,000 rpm for $2 \mathrm{~min}$. Lysate $(2 \mu \mathrm{l})$ was subsequently used in PCR. Based on the PCR results, the primer pair that amplified a characteristic product from diverse tumorigenic $A$. vitis was chosen.

Sensitivity and specificity of an $A$. vitis real-time PCR assay. A real-time SYBR green PCR assay was developed for A. vitis that would distinguish between tumorigenic and nontumorigenic strains. Primer efficiency of the A. vitis real-time PCR assay was determined on 10-fold serial dilutions of $A$. vitis strain S4 DNA extracted using the Ultra Clean Microbial DNA Isolation Kit (Mo Bio Laboratories Inc.). The concentration of nucleic acid used was 100 to $0.0001 \mathrm{ng} / \mu \mathrm{l}$. The real-time PCR reaction contained $12.5 \mu$ of SYBR Green mix (Bio-Rad, Hercules, CA) and $400 \mathrm{nM}$ virD2.for1 and virD2.rev1 in a total of $25 \mu \mathrm{l}$. PCR con- ditions were as follows: denaturation at $95^{\circ} \mathrm{C}$ for $5 \mathrm{~min}$; followed by 35 cycles of denaturation at $95^{\circ} \mathrm{C}$ for $20 \mathrm{~s}$, annealing at $50^{\circ} \mathrm{C}$ for $10 \mathrm{~s}$, and extension at $72^{\circ} \mathrm{C}$ for $60 \mathrm{~s}$. All reactions were conducted in a Bio-Rad CFX1000 real-time PCR machine. The experiment was repeated three times and mean cycle threshold (Ct) values and detection frequencies were recorded. Mean $\mathrm{Ct}$ values were plotted against $\log _{10} A$. vitis DNA dilutions and used to generate a standard curve. Linear regression analysis was conducted and the slope of the relationship was used to determine the amplification efficiency of the A. vitis real-time PCR assay using the equation efficiency $(\%)=10^{[-1 / \text { slope }]}-1 \times 100(3,16)$. To determine the specificity of the assay, the cell suspensions of 27 A. vitis strains (inclusive of tumorigenic and nontumorigenic strains), 4 A. tumefaciens strains, and 3 A. rhizogenes strains isolated from different hosts were tested, as mentioned above. In addition 12 unknown bacteria, isolated from enrichment broth inoculated with grapevine tissue, and Xylella fastidiosa, a pathogenic bacterium on grapevines, were also tested.

Extraction and enrichment of $A$. vitis DNA. The efficacy of $\mathrm{MCH}, \mathrm{IMS}$, and Powerfood DNA extraction methods followed by real-time PCR was compared with direct real-time PCR for detection of $A$. vitis. The methods used are described below.

Cell suspension preparation. Serial dilutions (10-fold) of $A$. vitis strain S4 cells of $\approx 1 \times 10^{8}$ to $1 \times 10^{1} \mathrm{CFU} / \mathrm{ml}$ were prepared in $1 \times$ phosphate buffered saline (PBS) solution $(137 \mathrm{mM} \mathrm{NaCl}$, $5.6 \mathrm{mM} \mathrm{Na} 2 \mathrm{HPO}_{4}, 2.7 \mathrm{mM} \mathrm{KCl}$, and $1.5 \mathrm{mM} \mathrm{KH} \mathrm{PO}_{4}$ ). The suspensions were used to determine the sensitivity of each assay. For direct real-time PCR, bacterial cells were pelleted by centrifugation at 13,000 rpm for $3 \mathrm{~min}$ and suspended in $1 \mathrm{ml}$ of water. Suspended cells were boiled for $10 \mathrm{~min}$ and $2 \mu \mathrm{l}$ was used in direct real-time PCR. To determine the specificity of the $\mathrm{MCH}$ and IMS assays, the A. vitis, A. tumefaciens, and A. rhizogenes strains mentioned previously were used. Suspensions $\left(1 \times 10^{8}\right.$ $\mathrm{CFU} / \mathrm{ml}$ ) of the different strains were made in $1 \times \mathrm{PBS}$ and suspensions were used in MCH or IMS as mentioned previously.

MCH. To facilitate MCH, a 74-bp capture probe was designed based on nucleotide sequence of the regions flanking the real-time PCR target sequence of virD2. The capture probe, VITIS, was modified at the $5^{\prime}$ end with biotin and triethylene glycol (www. idtdna.com) to allow attachment to streptavidin-coated magnetic beads (New England BioLabs). Briefly, beads (20 $\mu \mathrm{l} / \mathrm{sample})$ were washed with binding washing $(\mathrm{BW})$ buffer $(10 \mathrm{mM}$ TrisHCL, $1 \mathrm{mM}$ EDTA, and $100 \mathrm{mM} \mathrm{NaCl}$ ) to remove the storage solution (21). The beads were then suspended in $1 \mathrm{ml}$ of $\mathrm{BW}$ buffer and $2 \mathrm{ng}$ of probe was added per sample. The beads were incubated at $25^{\circ} \mathrm{C}$ for $1 \mathrm{~h}$ with agitation in a hybridization oven. The beads were collected and washed three times with BW buffer before being chemically denatured with denaturation (DN) solution $(0.125 \mathrm{M} \mathrm{NaOH}$ and $0.1 \mathrm{M} \mathrm{NaCl})$ for $15 \mathrm{~min}$ at $25^{\circ} \mathrm{C}$. Conjugated beads were again washed three times with $1 \mathrm{ml}$ of $\mathrm{BW}$ before being suspended in the original volume of BW buffer. Each 10-fold serial dilution of A. vitis strain S4 (1 ml) was pelleted and cells were suspended in $1 \mathrm{ml}$ of Dig Easy Hybridization buffer (Roche, Indianapolis, IN) with $250 \mu \mathrm{l}$ of $0.1-\mathrm{mm}$ glass beads (BioSpec Products, Bartlesville, OK). Samples were mechanically lysed for $10 \mathrm{~min}$ by bead-beating on a vortex adapted with a Mo Bio tube holder. Beads and cell debris were pelleted

TABLE 1. Agrobacterium vitis-specific oligonucleotides used for magnetic capture hybridization and real-time polymerase chain reaction

\begin{tabular}{|c|c|c|c|}
\hline Primer & Sequence $\left(5^{\prime} \rightarrow 3^{\prime}\right)^{\mathrm{a}}$ & Function & Reference \\
\hline virD2-F & CAA CTC ATC ATC CGC ATT GTG CC & A. vitis forward sequencing primer & This study \\
\hline virD2-R & TCGATGAAGTCGTTGCTGAAC & A. vitis reverse sequencing primer & This study \\
\hline virD2.For1 & TTG GAA TAT CTG TCC CGG AAG & A. vitis forward primer & This study \\
\hline virD2.Rev1 & CTT GTA CCA GCA GGG AAG CTT A & A. vitis reverse primer & This study \\
\hline \multirow[t]{2}{*}{ VITIS capture probe } & Bio-TEG-TGT GGA AGG CCG TAA GAT AGT TGT ATT GAC CTC & & \\
\hline & CCC CTT CGC CTG ACC CGA ACG TCT CGG CTG CCC A & A. vitis hybridization capture probe & This study \\
\hline
\end{tabular}

a Bio = biotin; TEG = triethylene glycol, 16-atom spacer arm. 
and the solution transferred to a new 2-ml tube (Sarstedt, Newton, NC). The DNA was denatured by boiling for $10 \mathrm{~min}$ followed by incubation on ice for $5 \mathrm{~min}$. Conjugated beads $(20 \mu \mathrm{l})$ were then added to each sample and samples were incubated at $37^{\circ} \mathrm{C}$ for $1 \mathrm{~h}$. After incubation, samples were placed on magnets and beads were washed three times with sterile HPLC water. Beads were suspended in $25 \mu \mathrm{l}$ of sterile HPLC water and boiled at $100^{\circ} \mathrm{C}$ for $10 \mathrm{~min}$ before being placed on ice for $5 \mathrm{~min}$. The eluted DNA solution $(8 \mu \mathrm{l})$ was used in real-time PCR.

IMS. Immunomagnetic beads (IMBs) coated with goat antimouse antibodies (New England BioLabs) were coated with a monoclonal anti- $A$. vitis antibody that is specific to both tumorigenic and nontumorigenic strains (8). IMBs (10 $\mu \mathrm{l} / \mathrm{sample})$ were washed with cold $1 \times$ PBS a total of four times. The beads were suspended in a final volume of $1 \mathrm{ml}$ of $1 \times$ PBS and mixed with $2 \mu \mathrm{l}$ of antiA. vitis antibody per sample before being incubated at $4^{\circ} \mathrm{C}$ for $1 \mathrm{~h}$ with mixing. Following incubation, the antibody-coated IMBs were washed four times with PBS-bovine serum albumen (BSA) and suspended in PBS-BSA. Samples to be tested were prepared for IMS by suspending pelleted cells in $1 \mathrm{ml}$ of PBS-BSA, to which $10 \mu \mathrm{l}$ of anti-A. vitis-coated beads was added, followed by incubation for $1 \mathrm{~h}$ at $4^{\circ} \mathrm{C}$. After incubation, the beads were rinsed once with PBS-BSA, followed by washing three times with sterile HPLC water. Magnetic beads were resuspended in $25 \mu \mathrm{l}$ of water. Samples were boiled to release DNA, $8 \mu \mathrm{l}$ of which was used for real-time PCR, and water was used as a negative control.

TABLE 2. Specificity of primer set 1 in real-time polymerase chain reaction (PCR) using different Agrobacterium vitis strains ${ }^{\mathrm{a}}$

\begin{tabular}{|c|c|c|c|c|c|c|c|}
\hline Bacteria & Opine ${ }^{b}$ & Location isolated & Host & Tumorigenic & $\begin{array}{l}\text { Direct real- } \\
\text { time PCR }\end{array}$ & $\begin{array}{l}\text { Detection } \\
\text { frequency }\end{array}$ & Source \\
\hline \multicolumn{8}{|l|}{ A. vitis } \\
\hline $1860(3)$ & $\ldots$ & Italy & Grapevine & + & + & $3 / 3$ & C. Bazzi \\
\hline AA25 & $\mathrm{n}$ & Afghanistan & Grapevine & + & + & $3 / 3$ & Ercolani \\
\hline AG125 & $\mathrm{o}, \mathrm{n}$ & North Greece & Grapevine & - & - & $0 / 3$ & Panagopoulos \\
\hline CG 49 & $\mathrm{o}, \mathrm{n}$ & New York, United States & Grapevine & + & + & $3 / 3$ & This laboratory \\
\hline CG 60 & $\mathrm{n}$ & New York, United States & Grapevine & + & + & $3 / 3$ & This laboratory \\
\hline CG 78 & $\mathrm{v}$ & New York, United States & Grapevine & + & + & $3 / 3$ & This laboratory \\
\hline CG 81 & $\mathrm{v}$ & Michigan, United States & Grapevine & + & + & $3 / 3$ & This laboratory \\
\hline CG 102 & ol & Virginia, United States & Grapevine & + & + & $3 / 3$ & This laboratory \\
\hline CG 106 & ol & Mississippi, United States & Grapevine & + & + & $3 / 3$ & This laboratory \\
\hline CG127 & $\mathrm{o}, \mathrm{n}$ & Lucas Vineyard, United States & Grapevine & + & + & $3 / 3$ & This laboratory \\
\hline CG 135 & $\mathrm{n}$ & Jim Knapp Farm, United States & Grapevine & + & + & $3 / 3$ & This laboratory \\
\hline CG158 & $\ldots$ & California, United States & Grapevine & + & + & $3 / 3$ & This laboratory \\
\hline CG 213 & $\mathrm{n}$ & New York, United States & Grapevine & + & + & $3 / 3$ & This laboratory \\
\hline CG 435 & ol & Virginia, United States & Grapevine & + & + & $3 / 3$ & This laboratory \\
\hline CG 442 & $\mathrm{n}$ & Washington, United States & Grapevine & + & + & $3 / 3$ & This laboratory \\
\hline CG 523 & $\ldots$ & New York, United States & Grapevine & - & - & $0 / 3$ & This laboratory \\
\hline CG 538 & $\ldots$ & Black Lake, New York, United States & Grapevine & - & - & $0 / 3$ & This laboratory \\
\hline CG 565 & $\ldots$ & Grands Isle Park, New York, United States & Grapevine & - & - & $0 / 3$ & This laboratory \\
\hline CG 679 & $\ldots$ & California, United States & Grapevine & + & + & $3 / 3$ & This laboratory \\
\hline CG 1100 & $\ldots$ & Taiwan & Grapevine & + & + & $3 / 3$ & Tze Chung Huang \\
\hline CG 1115 & $\ldots$ & Turkey & Grapevine & + & + & $3 / 3$ & Nihal Argun \\
\hline $\mathrm{F} 2 / 5$ & $\ldots$ & New York, United States & Grapevine & - & - & $0 / 3$ & This laboratory \\
\hline K306 & $\mathrm{o}, \mathrm{n}$ & South Australia & Grapevine & + & + & $3 / 3$ & K. Ophel \\
\hline NW11 & $\mathrm{v}$ & Germany & Grapevine & + & + & $3 / 3$ & Leon Otten \\
\hline NW113 & $\mathrm{v}$ & Germany & Grapevine & + & + & $3 / 3$ & Leon Otten \\
\hline NW-180 & o & Germany & Grapevine & + & + & $3 / 3$ & E. Bien \\
\hline S4 & $\mathrm{v}$ & Hungary & Grapevine & + & + & $3 / 3$ & E. Szegedi \\
\hline \multicolumn{8}{|c|}{ A. tumefaciens } \\
\hline $\mathrm{A} 432 / 75$ & $\ldots$ & Oregon, United States & Apple & + & + & $3 / 3$ & $\begin{array}{l}\text { M. L. Canfield, } \\
\text { L. W. Moore }\end{array}$ \\
\hline CG1028 & $\ldots$ & New York, United States & Cherry & + & + & $3 / 3$ & This laboratory \\
\hline C58 & $\ldots$ & New York & Cherry & + & + & $3 / 3$ & R. Dickey \\
\hline CG939 & $\ldots$ & Albany New York, United States & Daisy & + & + & $3 / 3$ & This laboratory \\
\hline \multicolumn{8}{|c|}{ A. rhizogenes } \\
\hline CG 907 & $\ldots$ & New York, United States & Hilton raspberry & + & + & $3 / 3$ & This laboratory \\
\hline CG 1063 & $\ldots$ & Illinois, United States & Euonymus & + & + & $3 / 3$ & This laboratory \\
\hline CG 1109 & $\ldots$ & California, United States & Walnut & + & + & $3 / 3$ & This laboratory \\
\hline \multicolumn{8}{|l|}{ Unknown $^{c}$} \\
\hline A & $\ldots$ & New York, United States & Grapevine & $\ldots$ & - & $0 / 3$ & This laboratory \\
\hline $\mathrm{B}$ & $\ldots$ & New York, United States & Grapevine & $\ldots$ & - & $0 / 3$ & This laboratory \\
\hline $\mathrm{C}$ & $\ldots$ & New York, United States & Grapevine & $\ldots$ & - & $0 / 3$ & This laboratory \\
\hline $\mathrm{D}$ & $\ldots$ & New York, United States & Grapevine & $\ldots$ & - & $0 / 3$ & This laboratory \\
\hline $\mathrm{E}$ & $\ldots$ & New York, United States & Grapevine & $\ldots$ & - & $0 / 3$ & This laboratory \\
\hline $\mathrm{F}$ & $\ldots$ & New York, United States & Grapevine & $\ldots$ & - & $0 / 3$ & This laboratory \\
\hline $\mathrm{G}$ & $\ldots$ & New York, United States & Grapevine & $\ldots$ & - & $0 / 3$ & This laboratory \\
\hline $\mathrm{H}$ & $\ldots$ & New York, United States & Grapevine & $\ldots$ & - & $0 / 3$ & This laboratory \\
\hline I & $\ldots$ & New York, United States & Grapevine & $\ldots$ & - & $0 / 3$ & This laboratory \\
\hline $\mathrm{J}$ & $\ldots$ & New York, United States & Grapevine & $\ldots$ & - & $0 / 3$ & This laboratory \\
\hline $\mathrm{K}$ & $\ldots$ & New York, United States & Grapevine & $\ldots$ & - & $0 / 3$ & This laboratory \\
\hline $\mathrm{L}$ & $\ldots$ & New York, United States & Grapevine & $\ldots$ & - & $0 / 3$ & This laboratory \\
\hline \multicolumn{8}{|c|}{ Xylella fastidiosa } \\
\hline Temecula & $\ldots$ & California, United States & Grapevine & $\ldots$ & - & $0 / 3$ & Steven Lindow \\
\hline $\mathrm{H}_{2} \mathrm{O}$ & $\ldots$ & $\ldots$ & $\ldots$ & $\ldots$ & - & $0 / 3$ & $\ldots$ \\
\hline
\end{tabular}

a The experiment was repeated three times.

b Abbreviations: $\mathrm{n}=$ nopaline, $\mathrm{o}=$ octopine, $\mathrm{v}=$ vitopine, and $\mathrm{ol}=$ octopine/cucumopine plasmid with large TA region (27).

c Unknown bacteria isolated from enrichment broth inoculated with vacuum extract collected from grapevine tissue. 
Powerfood DNA extraction. Powerfood DNA extraction was conducted according to the manufacturer's instructions. Briefly, $1 \mathrm{ml}$ of each 10-fold dilution of A. vitis strain S4 cells was pelleted and the supernatant was completely removed. Cells were suspended in Powerfood DNA extraction buffer 2 and DNA was extracted according to the manufacturer's instructions. DNA was eluted from the column using $80 \mu \mathrm{l}$ of water, $5 \mu \mathrm{l}$ of which was used for real-time PCR.

Detection of $A$. vitis in artificially inoculated grapevines. To determine the efficacy of each method for detection of A. vitis, grapevine ('Cabernet Franc') tissue was artificially inoculated with dilutions of $A$. vitis strain S4. The vines used were initially propagated from tissue culture and had no visual crown gall infections. Six nodes from each dormant Cabernet Franc grapevine tissue was cut into $0.5-\mathrm{cm}$ pieces and placed in $5 \mathrm{ml}$ of $10^{7}$, $10^{5}, 10^{3}$, or $10^{1} \mathrm{CFU} / \mathrm{ml}$ suspensions of $A$. vitis strain S4 and subjected to a vacuum (to help facilitate release of bacteria from xylem vessels) for $2 \mathrm{~min}$ for a total of three times. The solution was removed and added to nutrient broth (NB) supplemented with cycloheximide (100 mg/liter). Previously, we determined that NB would support growth of S4 when as few as 1 to 10 cells were added to the medium. Inoculated NB (2 ml) was removed after 1, 2, or 3 days of incubation and the cells were pelleted by centrifugation at 13,000 rpm for $5 \mathrm{~min}$. Nucleic acids were extracted using $\mathrm{MCH}$, IMS, or Powerfood protocols followed by real-time PCR, as described above. As a positive control, crown gall tissue was placed in $1 \times$ PBS and exposed to a vacuum, after which the supernatant was used to inoculate media, and samples were collected at 1, 2, and 3 days after inoculation and tested as described above.

Detection of $\boldsymbol{A}$. vitis in naturally infected grapevines. Two dormant canes were collected from 16 crown-gall-infected plants from a 'Pinot Gris' vineyard in New York. Four basal nodes from each cane were cut into $0.5-\mathrm{cm}$ pieces and placed in $5 \mathrm{ml}$ of $1 \times$ PBS. The samples were subjected to a vacuum for 2-min intervals three times. The suspension was removed and used to inoculate $18 \mathrm{ml}$ of $\mathrm{NB}$ supplemented with cycloheximide $(100 \mathrm{mg} / \mathrm{liter})$ followed by incubation at $28^{\circ} \mathrm{C}$. Broth $(2 \mathrm{ml})$ was collected at 3 days after inoculation. Samples were centrifuged for $5 \mathrm{~min}$ at $13,000 \mathrm{rpm}$ and concentrated cells were subjected to MCH, IMS, and Powerfood DNA extraction protocols followed by real-time PCR. If all samples could not be run on same day, the concentrated bacteria were stored at $4^{\circ} \mathrm{C}$.

\section{RESULTS}

Development of real-time PCR primers for tumorigenic A. vitis detection. A 630-bp fragment of virD2 gene was ampli-

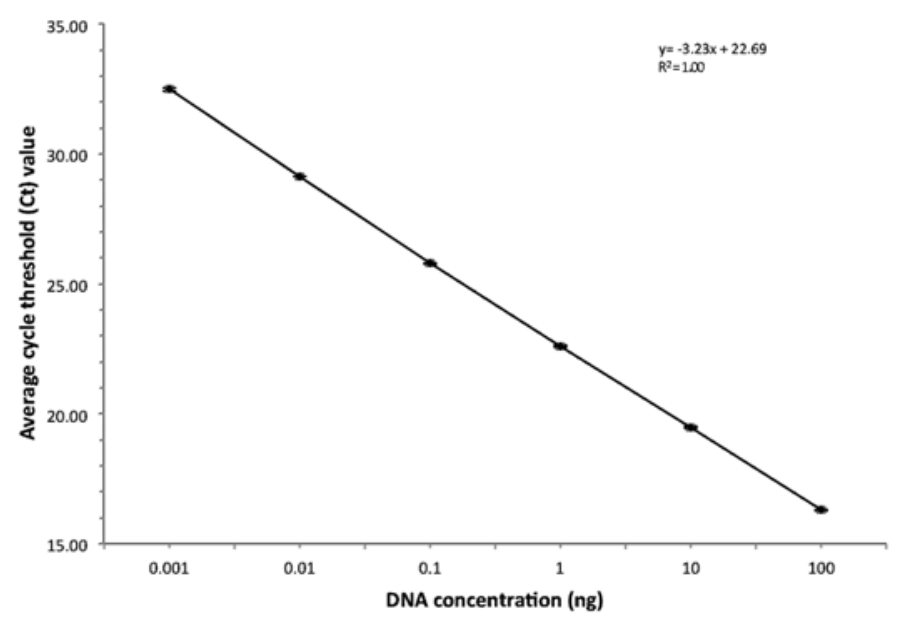

Fig. 1. Linear regression of 10-fold dilutions of Agrobacterium vitis strain S4 DNA against corresponding mean cycle threshold values. Data points represent the means of three separate real-time polymerase chain reactions. fied with primer pair virD2-F and virD2-R from all seven of the A. vitis strains tested. Sequencing indicated that the cloned PCR products were fragments of the virD2 gene. Alignment of DNA sequences from the seven A. vitis strains and A. vitis strain $\mathrm{S} 4$ showed that the identities within the region of the virD2 gene were $>99 \%$ similar. From these sequencing results, four primer pairs were generated. Each was used in conventional PCR with the 27 A. vitis strains listed in Table 2, which included the 7 strains mentioned above. Primer sets 2 and 4 were unable to amplify a characteristic product from all the strains; primer set 3 amplified multiple bands from all strains, including the nontumorigenic strains (data not shown). Therefore, primer set 1 was used going forward in development of the detection assay (Table 1).

Sensitivity and specificity of an $A$. vitis real-time PCR assay. The amplification efficiency of primer set 1, virD2.For1 and virD2.Rev1, was determined using linear regression analysis of the graph generated of $\log _{10} 10$-fold serial dilutions of $A$. vitis DNA (1.0 to $0.0001 \mathrm{ng} / \mu \mathrm{l}$ ) versus $\mathrm{Ct}$ value. An $R^{2}$ value of 1.00 indicated a very strong correlation between DNA concentration and the $\mathrm{Ct}$ values generated, suggesting that primer set 1 was highly efficient in amplification of the virD2 target sequence (Fig. 1). The threshold of detection using purified A. vitis strain S4 DNA was $0.001 \mathrm{ng} / \mu \mathrm{l}$, which was detected with $100 \%$ frequency, except for $0.0001 \mathrm{ng} / \mu \mathrm{l}$ and water, which remained negative.

Specificity of the virD2.For1 and virD2.Rev1 primer set was determined using 27 A. vitis strains, 4 A. tumefaciens strains, and 3 A. rhizogenes strains. The assay was able to detect all the tumorigenic A. vitis, A. tumefaciens, and A. rhizogenes strains tested (Table 2). Nontumorigenic A. vitis strains such as F2/5 and CG538 were not detected. The primers were also tested against 12 unknown bacteria isolated from enrichment broth inoculated with vacuum extract from grape tissue and against $X$. fastidiosa. Bacteria other than tumorigenic strains of Agrobacterium did not yield a positive result and were similar to the water sample used as a negative control. It was observed that the melting temperature varied between $A$. vitis strains (likely due to variance in virD2 sequence), with values of 84.5 to $88^{\circ} \mathrm{C}$; the melting temperature of $A$. vitis strain $\mathrm{S} 4$ was $85^{\circ} \mathrm{C}$.

Development of MCH and IMS real-time PCR assays for $A$. vitis detection. Sensitivity of $\mathrm{MCH}$ and IMS real-time PCR assays were compared with direct real-time PCR using 10-fold serial dilutions of $A$. vitis strain $\mathrm{S} 4$ cells. The threshold of detection for direct real-time PCR was $\approx 10^{5} \mathrm{CFU} / \mathrm{ml}$, with a frequency of $33 \%$ and a mean $\mathrm{Ct}$ value of 31.80 (Table 3). $\mathrm{Ct}$ values for cell concentrations of $10^{8}$ to $10^{6} \mathrm{CFU} / \mathrm{ml}$ were 23.89 to 29.39 (Table 3). These dilutions were detected with $100 \%$ frequency, except for $10^{6} \mathrm{CFU} / \mathrm{ml}$, which had a detection frequency of $66 \%$. Both $\mathrm{MCH}$ and IMS had detection thresholds of $10^{1}$ $\mathrm{CFU} / \mathrm{ml}$, with detection frequencies (and $\mathrm{Ct}$ values) of $33 \%$ (30.74) and 66\% (28.9), respectively. Powerfood extraction had a detection threshold of $10^{4} \mathrm{CFU} / \mathrm{ml}$, with a frequency of $33 \%$. $\mathrm{MCH}$ and IMS real-time PCR were 1,000-fold more sensitive than Powerfood DNA extraction and 10,000-fold more sensitive than direct real-time PCR. MCH real-time PCR had $<100 \%$ detection at $10^{3}, 10^{2}$, and $10^{1} \mathrm{CFU} / \mathrm{ml}$, with 66,66 , and $33 \%$ frequency, respectively. IMS real-time PCR also had samples with $<100 \%$ detection frequency, with $10^{3}(66 \%), 10^{2}(33 \%)$, and $10^{1}$ (66\%) CFU/ml, respectively.

The specificity of the MCH and IMS real-time PCR assay for detection of $A$. vitis was tested using $10^{8} \mathrm{CFU} / \mathrm{ml}$ of the 27 A. vitis strains previously mentioned to determine the ability of these methods to detect diverse bacteria. MCH and IMS real-time PCR assays detected only tumorigenic strains (Table 4), whereas nontumorigenic strains such as CG523 and CG565 remained negative after real-time PCR. Only $\mathrm{MCH}$ was used to test strains other than $A$. vitis. All the A. tumefaciens and A. rhizogenes strains tested positive with $\mathrm{MCH}$. The buffer-only and water-negative 
controls did not give positive results with either MCH or IMS real-time PCR.

Detection of $A$. vitis in artificially inoculated grapevines. $\mathrm{MCH}$, IMS and Powerfood DNA extraction techniques were compared using vine tissue artificially inoculate with $A$. vitis strain S4 cells. IMS was found to be the only method able to $\operatorname{detect} A$. vitis on grapevines artificially inoculated with bacteria at
$10^{1} \mathrm{CFU} / \mathrm{ml}$ at 1 day postinoculation (dpi) in NB (Table 5). At higher concentrations of $10^{2}, 10^{3}, 10^{5}$, and $10^{7} \mathrm{CFU} / \mathrm{ml}$, detection frequency was 33 to $100 \%$. The overall frequency of detection of IMS improved with higher inoculum densities and longer incubation times of 2 and 3 days. The MCH real-time PCR assay detected A. vitis in samples inoculated with bacteria at $10^{1} \mathrm{CFU} / \mathrm{ml}$ at 2 and 3 dpi but not at $1 \mathrm{dpi}$. It is possible that, at $1 \mathrm{dpi}$, the

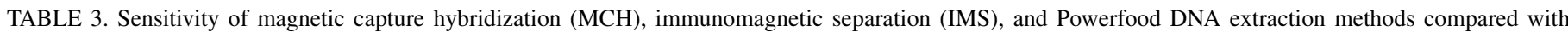
direct real-time polymerase chain reaction (PCR) using 10-fold serial dilutions of Agrobacterium vitis strain S4 cell suspensions ${ }^{\mathrm{a}}$

\begin{tabular}{|c|c|c|c|c|c|c|c|c|}
\hline \multirow[b]{2}{*}{ A. vitis $(\approx \mathrm{CFU} / \mathrm{ml})$} & \multicolumn{2}{|c|}{ Direct real-time PCR } & \multicolumn{2}{|c|}{ MCH real-time PCR } & \multicolumn{2}{|c|}{ IMS real-time PCR } & \multicolumn{2}{|c|}{ Powerfood real-time PCR } \\
\hline & $\mathrm{Ct} \pm \mathrm{SD}$ & Freq & $\mathrm{Ct} \pm \mathrm{SD}$ & Freq & $\mathrm{Ct} \pm \mathrm{SD}$ & Freq & $\mathrm{Ct} \pm \mathrm{SD}$ & Freq \\
\hline $10^{8}$ & $21.15 \pm 0.32$ & $3 / 3$ & $18.46 \pm 4.11$ & $3 / 3$ & $21.75 \pm 2.42$ & $3 / 3$ & $19.61 \pm 1.72$ & $3 / 3$ \\
\hline $10^{7}$ & $25.59 \pm 1.35$ & $3 / 3$ & $18.53 \pm 1.12$ & $3 / 3$ & $24.79 \pm 2.59$ & $3 / 3$ & $22.42 \pm 2.65$ & $3 / 3$ \\
\hline $10^{6}$ & $29.26 \pm 0.69$ & $2 / 3$ & $22.11 \pm 1.36$ & $2 / 3$ & $27.55 \pm 1.72$ & $3 / 3$ & $26.84 \pm 1.95$ & $3 / 3$ \\
\hline $10^{5}$ & $32.72 \pm 0.59$ & $2 / 3$ & $25.38 \pm 1.01$ & $3 / 3$ & $29.81 \pm 4.44$ & $3 / 3$ & $29.13 \pm 1.2$ & $2 / 3$ \\
\hline $10^{4}$ & 0.00 & $0 / 3$ & $29.60 \pm 0.38$ & $3 / 3$ & $32.12 \pm 2.63$ & $3 / 3$ & 31.75 & $1 / 3$ \\
\hline $10^{3}$ & 0.00 & $0 / 3$ & $29.74 \pm 1.68$ & $1 / 3$ & $30.19 \pm 3.11$ & $2 / 3$ & 0.00 & $0 / 3$ \\
\hline $10^{2}$ & 0.00 & $0 / 3$ & $29.74 \pm 2.07$ & $3 / 3$ & 30.97 & $1 / 3$ & 34.12 & $0 / 3$ \\
\hline $10^{1}$ & 0.00 & $0 / 3$ & $30.74 \pm 2.03$ & $1 / 3$ & $28.90 \pm 3.05$ & $2 / 3$ & 0.00 & $0 / 3$ \\
\hline $\mathrm{H}_{2} \mathrm{O}$ & 0.00 & $0 / 3$ & 0.00 & $0 / 3$ & 0.00 & $0 / 3$ & 0.00 & $0 / 3$ \\
\hline Buffer & $\ldots$ & $\ldots$ & 0.00 & $0 / 3$ & 0.00 & $0 / 3$ & $\ldots$ & $\ldots$ \\
\hline
\end{tabular}

a The experiment was repeated three times. Average cycle threshold value $(\mathrm{Ct}) \pm$ standard deviation $(\mathrm{SD})$ and detection frequency $($ Freq) are shown.

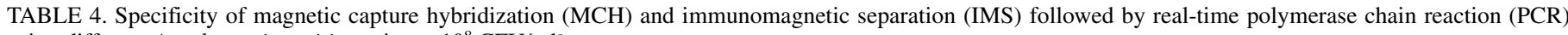
using different Agrobacterium vitis strains at $10^{8} \mathrm{CFU} / \mathrm{ml}^{\mathrm{a}}$

\begin{tabular}{|c|c|c|c|c|}
\hline \multirow[b]{2}{*}{ Strain $^{b}$} & \multicolumn{2}{|c|}{ MCH real-time PCR } & \multicolumn{2}{|c|}{ IMS real-time PCR } \\
\hline & $\mathrm{Ct} \pm \mathrm{SD}$ & $\operatorname{Tm}\left({ }^{\circ} \mathrm{C}\right) \pm \mathrm{SD}$ & $\mathrm{Ct} \pm \mathrm{SD}$ & $\mathrm{Tm}\left({ }^{\circ} \mathrm{C}\right) \pm \mathrm{SD}$ \\
\hline \multicolumn{5}{|l|}{ A. vitis } \\
\hline $1860(3)$ & $19.02 \pm 1.03$ & $86.50 \pm 0.00$ & $25.83 \pm 2.67$ & $85.00 \pm 0.00$ \\
\hline AA25 & $29.74 \pm 0.79$ & $86.75 \pm 0.35$ & 29.32 & 85.00 \\
\hline *AG125 & 0.00 & 0.00 & 0.00 & 0.00 \\
\hline CG 49 & $28.18 \pm 0.91$ & $86.50 \pm 0.00$ & $25.5 \pm 5.44$ & $86.25 \pm 0.18$ \\
\hline CG 60 & $24.44 \pm 7.52$ & $86.50 \pm 0.00$ & $26.91 \pm 5.25$ & $86.00 \pm 0.00$ \\
\hline CG 78 & 21.32 & $86.50 \pm 0.00$ & $25.48 \pm 1.72$ & $86.00 \pm 0.00$ \\
\hline CG 81 & $18.90 \pm 0.24$ & $86.50 \pm 0.00$ & $23.55 \pm 0.59$ & $85.00 \pm 0.00$ \\
\hline CG 102 & $28.73 \pm 0.31$ & $86.50 \pm 0.00$ & $27.77 \pm 3.41$ & $86.25 \pm 0.18$ \\
\hline CG 106 & $27.89 \pm 0.66$ & $87.50 \pm 0.00$ & $29.5 \pm 1.14$ & 86.50 \\
\hline CG 127 & $27.56 \pm 1.44$ & $86.50 \pm 0.00$ & $29.06 \pm 2.26$ & $86.25 \pm 0.18$ \\
\hline CG 135 & $28.38 \pm 1.01$ & $86.50 \pm 0.00$ & $26.59 \pm 4.31$ & $86.25 \pm 0.18$ \\
\hline CG 158 & $28.01 \pm 1.24$ & $87.00 \pm 0.00$ & $31.5 \pm 0.78$ & $86.00 \pm 0.00$ \\
\hline CG 213 & $27.61 \pm 2.71$ & $86.50 \pm 0.00$ & $26.98 \pm 5.05$ & $86.00 \pm 0.00$ \\
\hline CG 435 & $28.33 \pm 1.38$ & $87.50 \pm 0.00$ & $27.86 \pm 2.35$ & $86.00 \pm 0.00$ \\
\hline CG 442 & $28.65 \pm 0.51$ & $86.75 \pm 0.35$ & $27.22 \pm 2.78$ & $86.00 \pm 0.00$ \\
\hline CG 523 & 32.84 & 0.00 & 0.00 & 0.00 \\
\hline${ }^{*} \mathrm{CG} 538$ & 0.00 & 0.00 & 0.00 & 0.00 \\
\hline${ }^{*} \mathrm{CG} 565$ & 0.00 & 0.00 & 0.00 & 0.00 \\
\hline CG 679 & $28.63 \pm 2.07$ & $86.50 \pm 0.00$ & $30.76 \pm 1.97$ & $86.00 \pm 0.00$ \\
\hline CG 1100 & $27.89 \pm 0.88$ & $86.50 \pm 0.00$ & $29.45 \pm 1.34$ & $85.75 \pm 0.18$ \\
\hline CG 1115 & $28.33 \pm 1.43$ & $87.00 \pm 0.00$ & $27.15 \pm 1.55$ & $85.5 \pm 0.18$ \\
\hline$* \mathrm{~F} 2 / 5$ & 0.00 & 0.00 & 0.00 & 0.00 \\
\hline K306 & $28.46 \pm 0.82$ & $86.25 \pm 0.35$ & $27.1 \pm 5.09$ & $86.00 \pm 0.00$ \\
\hline NW11 & $19.67 \pm 0.13$ & $86.75 \pm 0.35$ & $21.35 \pm 0.09$ & $85.00 \pm 0.00$ \\
\hline NW113 & $19.54 \pm 0.59$ & $86.50 \pm 0.00$ & $22.83 \pm 1.34$ & $85.00 \pm 0.00$ \\
\hline NW-180 & $28.19 \pm 1.50$ & $86.75 \pm 0.35$ & $28.61 \pm 2.02$ & $86.25 \pm 0.18$ \\
\hline $\mathrm{S} 4$ & $20.26 \pm 1.67$ & $86.50 \pm 0.00$ & $25.96 \pm 0.14$ & $85.00 \pm 0.00$ \\
\hline \multicolumn{5}{|c|}{ A. tumefaciens } \\
\hline A432/75 & $19.21 \pm 1.45$ & $86.83 \pm 0.29$ & N/A & N/A \\
\hline CG 1028 & $19.07 \pm 2.56$ & $86.7 \pm 0.58$ & N/A & N/A \\
\hline C58 & $22.37 \pm 0.03$ & $87.50 \pm 0.00$ & N/A & N/A \\
\hline CG 939 & 24.8 & 86.5 & N/A & N/A \\
\hline \multicolumn{5}{|c|}{ A. rhizogenes } \\
\hline CG 907 & $18.62 \pm 1.66$ & $86.83 \pm 0.29$ & N/A & N/A \\
\hline CG 1063 & $19.05 \pm 2.44$ & $86.83 \pm 0.29$ & N/A & N/A \\
\hline CG 1109 & $17.11 \pm 0.89$ & $87.00 \pm 0.00$ & N/A & N/A \\
\hline Buffer & 0.00 & 0.00 & 0.00 & 0.00 \\
\hline Control & $18.79 \pm 0.49$ & $85.00 \pm 0.00$ & $20.06 \pm 0.56$ & $85.00 \pm 0.00$ \\
\hline $\mathrm{H}_{2} \mathrm{O}$ & 0.00 & 0.00 & 0.00 & 0.00 \\
\hline
\end{tabular}

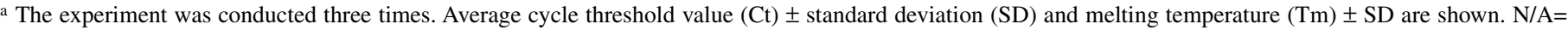
samples were not tested with IMS.

b Asterisks (*) indicate nontumorigenic strains and Control = PCR-positive control. 
A. vitis populations was below the detection threshold of the assay, and non-target DNA concentration may have been inhibitory. DNA extracted by $\mathrm{MCH}$ had $100 \%$ detection frequency at the higher initial inoculum concentrations of $10^{3}, 10^{5}$, and $10^{7}$. At lower inoculum densities of $10^{1}$ and $10^{2} \mathrm{CFU} / \mathrm{ml}$, the frequency of detection was 0 to $100 \%$. However, the frequency of detection with $\mathrm{MCH}$ is significantly enhanced compared with the Powerfood DNA extraction method, which did not detect $A$. vitis in samples inoculated with $10^{1} \mathrm{CFU} / \mathrm{ml}$ at any of the days tested or consistently at $10^{2} \mathrm{CFU} / \mathrm{ml}$. At higher concentrations and with longer incubation times, Powerfood DNA extraction followed by real-time PCR was able to detect $A$. vitis. All three methods were able to detect $A$. vitis in gall tissue taken from a naturally infected grapevine after incubation at all the days tested. The buffer and water-only controls remained negative.

Detection of $\boldsymbol{A}$. vitis in naturally infected grapevines. $\mathrm{MCH}$, IMS, and Powerfood DNA extraction allowed detection of $A$. vitis in naturally infected grapevines. In all, $18.75 \%$ of vines tested with Powerfood DNA extraction or IMS real-time PCR were positive, whereas $68.75 \%$ of the samples tested were found to be positive with MCH real-time PCR (Table 6). All the samples found positive by IMS or Powerfood DNA extraction followed by real-time PCR were also found to be positive by $\mathrm{MCH}$. Interestingly, not all samples found positive by IMS real-time PCR were positive using Powerfood followed by real-time PCR and vice versa. One example was vine 9, which was positive using IMS real-time PCR but negative by Powerfood DNA extraction and real-time PCR. The opposite trend was observed with vine 16, which was negative by IMS real-time PCR but found to be positive by Powerfood DNA extraction and real-time PCR. Tissue taken from asymptomatic vines, grown in an experimental vineyard plot, that were initially propagated via shoot tip culture were used as a negative control and assumed to be absent on A. vitis. These were found to be negative using the three methods to test for $A$. vitis. $\mathrm{MCH}$ allowed a significant increase in sensitivity of detection compared with IMS and Powerfood DNA extraction. Buffer and water served as negative controls and did not produce a PCR product.

TABLE 5. DNA extraction magnetic capture hybridization ( $\mathrm{MCH})$, immunomagnetic separation (IMS), and Powerfood followed by real-time polymerase chain reaction for detection of 10-fold serial dilutions of Agrobacterium vitis S4 in artificially inoculated grapevine cutting tissues ${ }^{\mathrm{a}}$

\begin{tabular}{lccc}
\hline & \multicolumn{2}{c}{ DNA extraction method detection frequency } \\
\cline { 2 - 4 } Tissues $^{\text {b }}$ & MCH & IMS & Powerfood \\
\hline $10^{1}, 1$ day & $0 / 3$ & $1 / 3$ & $0 / 3$ \\
$10^{1}, 2$ days & $2 / 3$ & $1 / 3$ & $0 / 3$ \\
$10^{1}, 3$ days & $1 / 3$ & $1 / 3$ & $0 / 3$ \\
$10^{2}, 1$ day & $3 / 3$ & $1 / 3$ & $1 / 3$ \\
$10^{2}, 2$ days & $3 / 3$ & $1 / 3$ & $1 / 3$ \\
$10^{2}, 3$ days & $1 / 3$ & $1 / 2$ & $0 / 3$ \\
$10^{3}, 1$ day & $3 / 3$ & $2 / 3$ & $1 / 3$ \\
$10^{3}, 2$ days & $3 / 3$ & $2 / 3$ & $2 / 3$ \\
$10^{3}, 3$ days & $3 / 3$ & $3 / 3$ & $2 / 3$ \\
$10^{5}, 1$ day & $3 / 3$ & $1 / 3$ & $3 / 3$ \\
$10^{5}, 2$ days & $3 / 3$ & $2 / 3$ & $3 / 3$ \\
$10^{5}, 3$ days & $3 / 3$ & $2 / 3$ & $2 / 3$ \\
$10^{7}, 1$ day & $3 / 3$ & $1 / 3$ & $3 / 3$ \\
$10^{7}, 2$ days & $3 / 3$ & $2 / 3$ & $2 / 3$ \\
$10^{7}, 3$ days & $3 / 3$ & $2 / 3$ & $3 / 3$ \\
$\mathrm{R} 3,1$ day & $2 / 2$ & $1 / 2$ & $1 / 2$ \\
$\mathrm{R} 3,2$ days & $2 / 2$ & $2 / 2$ & $1 / 2$ \\
$\mathrm{R} 3,3$ days & $2 / 2$ & $2 / 2$ & $1 / 2$ \\
Noninfected & $0 / 3$ & $0 / 3$ & $0 / 3$ \\
Buffer & $0 / 2$ & $0 / 2$ & $\mathrm{~N} / \mathrm{A}$ \\
$\mathrm{H}_{2} \mathrm{O}$ & $0 / 3$ & $0 / 3$ & $0 / 3$ \\
\hline
\end{tabular}

a Experiments were done three times. N/A = samples were not tested.

${ }^{b}$ Inoculated grape tissues were incubated in nutrient broth enrichment medium for 1 to 3 days prior to running assays, as described in text. R3 = gall tissue from naturally infected grapevine and Noninfected = noninfected cane.

\section{DISCUSSION}

Crown gall of grape is an economically important disease that affects grape production worldwide. Management of disease occurrence and spread of the pathogen can be accomplished by using material free of $A$. vitis. To accomplish this, efficient and accurate indexing methods must be available to test propagation material for the pathogen. Previous protocols included callusing or flushing cuttings with buffer followed by detection of opines or observation of bacterial colonies on semiselective media $(4,11)$. Identification of the isolated bacteria can be accomplished by serology, identification of biochemical markers, or PCR-based protocols $(7,8,14,20,30)$. These methods are time consuming, because callusing alone can take weeks to complete, and may be inaccurate due to lack of sensitivity. Therefore, a more timeefficient method with improved accuracy and sensitivity is required. Real-time PCR is one such method because it allows fast and accurate detection and diagnosis of pathogens such as $X$. fastidiosa, Grapevine fanleaf virus, and Xanthomonas campestris $(5,13,31)$.

Pathogenic Agrobacterium spp. are host to the Ti plasmid, which confers tumorigenesis (36). This makes the genes present on the Ti plasmid ideal targets for PCR detection and allows specific identification of Agrobacterium spp. and differentiation of tumorigenic and nontumorigenic strains. The virD2 gene, which resides on the Ti plasmid, encodes an endonuclease required for processing and transfer of T-DNA (25). Therefore, the virD2 gene is essential for virulence, making it an ideal target for PCR (32). Unfortunately, sequence variability exists between Agrobacterium spp. and even between strains, and this may lead to false negatives because of the inability of primers to bind successfully to the target sequence. To overcome this problem, the $5^{\prime}$ region of the virD2 gene of seven $A$. vitis isolates was sequenced and the data used to create four real-time primer sets for A. vitis detection. The first 684 bases were reported to be most conserved between plasmids expressing different opines; from this, we extrapolated that the $5^{\prime}$ region may be the most conserved between strains and, therefore, would be an ideal target for

TABLE 6. Comparison of magnetic capture hybridization $(\mathrm{MCH})$, immunomagnetic separation (IMS), and Powerfood DNA extraction followed by realtime polymerase chain reaction (PCR) for detection of Agrobacterium vitis in dormant cuttings from 'Pinot Gris' grapevines naturally infected with crown gall $^{\mathrm{a}}$

\begin{tabular}{lccc}
\hline & \multicolumn{3}{c}{ DNA extraction method } \\
\cline { 2 - 4 } Vine & MCH & IMS & Powerfood \\
\hline 1 & + & - & - \\
2 & + & - & - \\
3 & + & - & - \\
4 & - & - & - \\
5 & + & - & - \\
6 & + & + & + \\
7 & + & - & - \\
8 & + & - & - \\
9 & + & + & - \\
10 & + & - & - \\
11 & - & - & - \\
12 & + & - & - \\
13 & + & - & - \\
14 & - & - & - \\
15 & - & - & + \\
16 & + & - & - \\
Noninfected cane & - & - & N/A \\
Buffer & - & + & + \\
PCR control & + & - & - \\
$\mathrm{H}_{2} \mathrm{O}$ & - & - & + \\
\hline
\end{tabular}

a Bacteria were vacuum extracted from dormant grapevine nodes and inoculated into nutrient broth. Bacteria were concentrated after 3 days, and DNA extraction followed by real-time PCR was done. N/A= samples were not tested. 
development of real-time PCR primers (32). Sequencing data indicated that the first few bases of the virD2 genes sequenced were not conserved, and this may explain the inconsistent PCR results observed when using the virD2A/virD2C primers with $A$. vitis (S. Kaewnum, personal communication). Even among the four primer sets designed, variability in specificity among the 27 A. vitis strains tested was observed. Of the four primer sets designed, primer set 1, designated virD2.for1/virD2.rev1, was found to amplify all the pathogenic A. vitis and A. tumefaciens strains tested. virD2.for1/virD2.rev1 had an amplification efficiency of $100 \%$, which is within the acceptable range of 80 to $115 \%$ (3). Along with the strong correlation between DNA concentration and $\mathrm{Ct}$ value, the results indicated that these primers were suitable for amplification of $A$. vitis. A real-time SYBR green assay was developed for A. vitis detection instead of a Taqman assay. Although a Taqman assay may be more specific, this increased specificity may be a disadvantage because the variability in the virD2 sequence may lead to a false negative; in addition, the expense of the Taqman probe may be cost prohibitive (2). Unfortunately, the SYBR Green assay has a disadvantage in that the SYBR Green dye binds nonspecifically to double-stranded DNA; therefore, we incorporated the melting temperature analysis to help discriminate nonspecific bands. The production of a $\mathrm{Ct}$ value and a melting temperature within the range of 84 to $88^{\circ} \mathrm{C}$ was used to determine a positive reaction. The variability in $\mathrm{Ct}$ value was not unexpected because different nucleic-acid make-up within the target region can lead to a variation in melting temperature (18). Samples were determined to be negative if they lacked both a $\mathrm{Ct}$ value and a melt curve within the established $A$. vitis range and in the event that there was a $\mathrm{Ct}$ value but no melt curve, as observed with the $10^{2}$ $\mathrm{CFU} / \mathrm{ml}$ Powerfood extracted sample in Table 3. The presence of a $\mathrm{Ct}$ value could be due to the presence of primer dimers or nonspecific amplification of a band that is not the expected size. The specificity of the primer set was tested with unknown bacteria isolated from enrichment media, A. rhizogenes, and $A$. tumefaciens from different hosts. The ability of the primers and the assay to detect $A$. tumefaciens from different hosts suggests that this method may be applicable to the detection of Agrobacterium spp. from plants other than grape.

$\mathrm{MCH}$ and IMS allow for selective concentration of target nucleic acid and whole cells, respectively. $\mathrm{MCH}$ is sensitive and specific and relies on a nucleic acid probe to bind to and concentrate target sequences. $\mathrm{MCH}$ has been adapted for detection of bacteria, fungi, and viruses from a wide variety of research fields $(1,16,24)$. IMS relies on antibodies for selective targeting of the pathogen for use in real-time PCR. Both methods are simple and rapid and allow concentration of a specific target.

The MCH and IMS real-time PCR assays were both 10,000fold and 1,000-fold more sensitive than direct real-time PCR and Powerfood DNA extraction followed by real-time PCR, respectively. For both assays, the frequency of detection decreased as concentration of bacterial cells decreased, indicating that sensitivity is affected by the amount of target present. The $\mathrm{MCH}$ and IMS real-time PCR assay were both specific to tumorigenic strains of $A$. vitis, and to A. rhizogenes and A. tumefaciens (in the case of $\mathrm{MCH}$ ). The antibody used for IMS is specific for A. vitis; hence, we did not use IMS for detection of A. tumefaciens (8). Nontumorigenic strains were not detected by $\mathrm{MCH}$ or IMS followed by real-time PCR. This was expected because the virD2 real-time primers were not able to detect these strains. Although IMS had a higher frequency of detection compared with $\mathrm{MCH}$ when using dilutions of pure cells, reliability of the assay decreased on artificially inoculated grapevine tissue and naturally infected tissue. In all, $75 \%$ of naturally infected vines tested with $\mathrm{MCH}$ were positive compared with $25 \%$ for IMS and Powerfood DNA extraction. In the case of IMS, nontumorigenic A. vitis could bind the antibody and nontarget bacteria may also bind to the beads obscuring the target cells. Powerfood DNA extraction may be affected by the amount of background DNA from nontarget bacteria which can dilute A. vitis DNA, leading to false negatives; hence the need for an enrichment step such as $\mathrm{MCH}$ that specifically concentrates the target nucleic acid. Although MCH real-time PCR was the most sensitive of the methods tested, samples that tested negative may not be indicators that the entire vine is free of the pathogen because the distribution of A. vitis in vines is not known .

We have demonstrated the applicability of MCH real-time PCR for detection of $A$. vitis from grapevines and indicated that this protocol may also be adapted for detection of A. tumefaciens. This protocol has further potential to be used as a tool to study the distribution of the bacteria throughout grapevines which may help improve efficiency of sampling and testing of apparently healthy propagation tissue. $\mathrm{MCH}$ real-time PCR will also be a sensitive assay for reexamining the presence of $A$. vitis in environmental samples such as wild grape species, irrigation water, and soil.

\section{ACKNOWLEDGMENTS}

This research was partially funded by the United States Department of Agriculture (USDA) Animal and Plant Health Inspection Service National Clean Plant Network and USDA Federal Formula Funds. We thank B. Dehaven her technical assistance.

\section{LITERATURE CITED}

1. Amagliani, G., Omiccioli, E., Campo, A., Bruce, I. J., Brandi, G., and Magnani, M. 2006. Development of a magnetic capture hybridizationPCR assay for Listeria monocytogenes direct detection in milk samples. J. Appl. Microbiol. 100:375-383.

2. Amer, H. M., and Almajhdi, F. N. 2011. Development of a SYBR Green I based real-time RT-PCR assay for detection and quantification of bovine coronavirus. Mol. Cell Probes 25:101-107.

3. Arezi, B., Xing, W., Sorge, J. A., and Hogrefe, H. H. 2003. Amplification efficiency of thermostable DNA polymerases. Anal. Biochem. 321:226235.

4. Bazzi, C., Piazza, C., and Burr, T. J. 1987. Detection of Agrobacterium tumefaciens in grapevine cuttings. Bull. OEPP 17:105-112.

5. Berg, T., Tesoriero, L., and Hailstones, D. L. 2006. A multiplex real-time PCR assay for detection of Xanthomonas campestris from brassicas. Lett. Appl. Microbiol. 42:624-630.

6. Bini, F., Geider, K., and Bazzi, C. 2008. Detection of Agrobacterium vitis by PCR using novel virD2 gene-specific primers that discriminate two subgroups. Eur. J. Plant Pathol. 122:403-411.

7. Bini, F., Kuczmog, A., Putnoky, P., Otten, L., Bazzi, C., Burr, T. J., and Szegedi, E 2008. Novel pathogen-specific primers for the detection of Agrobacterium vitis and Agrobacterium tumefaciens. Vitis 47:181-189.

8. Bishop, A. L., Burr, T. J., Mittak, V. L., and Katz, B. H. 1989. A monoclonal antibody specific to Agrobacterium tumefaciens biovar 3 and its utilization for indexing grapevine propagation material. Phytopathology 79:995-998.

9. Burr, T. J., Bazzi, C., Sule, S., and Otten, L. 1998. Crown gall of grape: biology of Agrobacterium vitis and the development of disease control strategies. Plant Dis. 82:1288-1297.

10. Burr, T. J., Bishop, A. L., Katz, B. H., Blanchard, L. M., and Bazzi, C. 1987. A root-specific decay of grapevine caused by Agrobacterium tumefaciens and A. radiobacter Biovar 3. Phytopathology 77:1424-1427.

11. Burr, T. J., and Katz, B. 1984. Grapevine cuttings as potential sites of surviving and means of dissemination of Agrobacterium tumefaciens. Plant Dis. 68:976-978.

12. Burr, T. J., Reid, C. L., Yoshimura, M., Momol, E. A., and Bazzi, C. 1995. Survival and tumorigenicity of Agrobacterium vitis in living and decaying grape roots and canes in soil. Plant Dis. 79:677-682.

13. Cepin, U., Gutiérrez-Aguirre, I., Balažic, L., Pompe-Novak, M., Gruden, K., and Ravnikar, M. 2010. A one-step reverse transcription real-time PCR assay for the detection and quantitation of Grapevine fanleaf virus. J. Virol. Methods 170:47-56.

14. Eastwell, K. C., Willis, L. G., and Cavileer, T. D. 1995. A rapid and sensitive method to detect Agrobacterium vitis in grapevine cuttings using the Polymerase Chain Reaction. Plant Dis. 79:822-827.

15. Güven, K., and Mutlu, M. B. 2000. Development of immunomagnetic separation technique for isolation of Pseudomonas syringae pv. phaseolicola. Folia Microbiol. (Praha) 45:321-324. 
16. Ha, Y., Fessehaie, A., Ling, K. S., Wechter, W. P., Keinath, A. P., and Walcott, R. R. 2009. Simultaneous detection of Acidovorax avenae subsp. citrulli and Didymella bryoniae in cucurbit seedlots using magnetic capture hybridization and real-time polymerase chain reaction. Phytopathology 99:666-678.

17. Ha, Y., Kim, J., Denny, T. P., and Schell, M. A. 2012. A rapid, sensitive assay for Ralstonia solanacearum race 3 biovar 2 in plant and soil samples using magnetic beads and real-time PCR. Plant Dis. 96:258-264.

18. Helps, C., Lait, P., Tasker, S., and Harbour, D. 2002. Melting curve analysis of feline calicivirus isolates detected by real-time reverse transcription PCR. J. Virol. Methods 106:241-244.

19. Jacobsen, C. S. 1995. Microscale detection of specific bacterial DNA in soil with a magnetic capture-hybridization and PCR amplification assay. Appl. Environ. Microbiol. 61:3347-3352.

20. Jager, J., Lorenz, D., Plapp, R., and Eichhorn, K. W. 1989. Latent occurrence of Agrobacterium tumefaciens biovar 3 in grapevine (Vitis vinifera L.). Vitic. Enol. Sci. 44:14-20.

21. Johnson, K. L., and Walcott, R. R. 2012. Progress towards a real-time PCR assay for the simultaneous detection of Clavibacter michiganensis subsp. michiganensis and Pepino mosaic virus in tomato seed. J. Phytopathol. 160:353-363.

22. Kerr, A., and Panagopoulos, C. G. 1977. Biotypes of Agrobacterium radiobacter var. tumefaciens and their biological control. Phytopathology 90:172-179.

23. Lehoczky, J. 1971. Further evidences concerning the systemic spreading of Agrobacterium tumefaciens in the vascular system of grapevines. Vitis 10:215-221.

24. Miglino, R., Jodlowska, A., Pappu, H. R., and van Schadewijk, T. R. 2007. A semi-automated and highly sensitive streptavidin magnetic capture-hybridization RT-PCR assay: application to genus-wide or species-specific detection of several viruses of ornamental bulb crops. J. Virol. Methods 146:155-164.

25. Mysore, K. S., Bassuner, B., Deng, X. B., Darbinian, N. S., Motchoulski, A., Ream, W., and Gelvin, S. B. 1998. Role of the Agrobacterium tumefaciens VirD2 protein in T-DNA transfer and integration. Mol. Plant-
Microbe Interact. 11:668-683.

26. Ophel, K., and Kerr, A. 1990. Agrobacterium vitis sp. nov. for strains of Agrobacterium biovar 3 from grapevines. S. Int. J. Syst. Bacteriol. 40:236-241

27. Otten, L., de Ruffray, P., Momol, E. A., Momol, M. T., and Burr, T. J. 1996. Phylogenetic relationships between Agrobacterium vitis isolates and their Ti plasmids. Mol. Plant Microbe Biol. 9:782-786.

28. Peduto, F., Marchi, G., and Surico, G. 1998. Indexing Agrobacterium vitis in asymptomatic grapevine propagation material by two nested PCR assays Am. J. Enol. Vitic. 61:102-112.

29. Pulawska, J., and Sobiczewski, P. 2005. Development of a semi-nested PCR based method for sensitive detection of tumorigenic Agrobacterium in soil. J. Appl. Microbiol. 98:710-721.

30. Sawada, H., Leki, H., and Matsuda, I. 1995. PCR detection of Ti and Ri plasmids from phytopathogenic Agrobacterium strains. Appl. Environ. Microbiol. 61:828-831.

31. Schaad, N. W., Opgenorth, D., and Gaush, P. 2002. Real-time polymerase chain reaction for one-hour on-site diagnosis of Pierce's disease of grape in early season asymptomatic vines. Phytopathology 92:721-728.

32. Steck, T. R., Lin, T. S., and Kado, C. I. 1990. VirD2 gene product from the nopaline plasmid pTiC58 has at least two activities required for virulence. Nucleic Acids Res. 18:953-958.

33. Tarbah, F. A., and Goodman, R. N. 1986. Rapid detection of Agrobacterium tumefaciens in grapevine propagating material and the basis for an efficient indexing system. Plant Dis. 70:566-568.

34. Tu, S. I., Patterson, D., Briggs, C., Irwin, P., and Yu, L. 2001. Detection of immunomagnetically captured Escherichia coli O157:H7 by antibodyconjugated alkaline phosphatase. J. Ind. Microbiol. Biotechnol. 26:345349 .

35. Walcott, R. R., and Gitaitis, R. D. 2000. Detection of Acidovorax avenae subsp. citrulli in watermelon seed using immunomagnetic separation and the polymerase chain reaction. Plant Dis. 84:470-474.

36. Zaenaen, I., van Larebeke, N., Teuchy, H., Van Mantagu, M., and Schell. J. 1974. Supercoiled circular DNA in crown gall inducing Agrobacterium strains. J. Mol. Biol. 8:109-127. 